\title{
ANALYSIS OF THE TRINOM MIGRATION - FDI - COMPETITIVENESS. CASE STUDY: ROMANIA (2004-2015)
}

\author{
Ana Maria Talmaciu (Banu) ${ }^{1 *}$, Laura-Mariana Cismaş ${ }^{2}$ \\ ${ }^{1}$ West University of Timisoara, Romania \\ ${ }^{2}$ Department of Economics and Business Modelling, Faculty of Economics and Business \\ Administration, West University of Timisoara, Timisoara, Romania \\ ana.talmaciu@yahoo.com \\ laura.cismas@e-uvt.ro
}

\begin{abstract}
In the context of a global economy, increasingly competitive, the battle for the competitive advantage has become harsh. The attractiveness of countries which influence the international migration, generate opposite or complementary effects in the countries of origin and destination. Labor migration among highly qualified people stirred controversy on the impact on the economies of the countries involved in the international transfer of human capital. Labor migration, highly qualified or not, produce a change in the investor's behavior. They will be interested in investing in countries where the workforce is favoring either qualitatively, either financially, or both. The foreign direct investment fluctuates as the dynamics of migration increases. A country with a large number of highly skilled migrants can lose to foreign investors due to the lack of attractiveness of human capital, and, at the same time, a country with a large number of a trained environmental emigrant may be of interest to investors in search of cheap labor. This paper aims to examine the following hypothesis: to which extent the emigration influence the competitive level (measured by GDP) and the foreign direct investments in the origin country. The results confirm the economic theory, showing a correlation, but not a significative one, for the analized years.
\end{abstract}

Keywords: migration, competitiveness, foreign direct investment, correlation.

JEL classification: J21, J61, J31.

\section{Introduction}

The international migration, as a globalization effect, is a process that requires effective management of its effects both positive and negative. The transfer of knowledge and the mobility of production factors led to the development of innovative technologies and to potential growth, as well as to improved living standards of the citizens. In the context of a global economy, increasingly competitive, the battle for the competitive advantage has become harsh. The attractiveness of countries which influence the international migration, generate opposite or complementary effects in countries of origin and the destination.

Labor migration among highly qualified people stirred controversy on the impact on the economies of the countries involved in the international transfer of human capital. Most often this phenomenon is called "brain-drain" and usually, it occurs between low-income countries and high-income countries (Bein et al, 2008). Moreover, labor migration, highly qualified or not, produce a change in the investor's behavior. They will be interested in investing in countries where manpower favoring either qualitatively, either financially or both.The foreign direct investment fluctuates as the dynamics of migration increases. A country with a large number of highly skilled migrants can lose to foreign investors due to the lack of

\footnotetext{
* Corresponding author
} 
attractiveness of human capital, and, at the same time, a country with a large number of a trained environmental emigrant may be of interest to investors in search of cheap labor.

This phenomenon is specific to Romania too, as a country characterized by low income, nd the proportions it has taken becomes worrisome. The local labor market relaxation caused by massive emigration has not changed for the better the lives of those left behind and influenced their behavior toward immigration. A recent study (Goschin, 20013) demonstrated the Romanian's teenagers' intention to leave the country at least temporarily. This paper aims to examine the following hypothesis: to which extent the emigration influence the competitive level (measured by GDP) and the foreign direct investments in the origin country. The first part of the paper consists of a review of the literature who studied these relationships; we also present the work methodology. In the second part of the paper we use an econometric method to examine the relationship between these variables; finally, the data are interpreted. In the last part of the paper, we comment on the results and propose a number of policy lessons.

\section{Literature review}

The link between migration and competitiveness, seen as economic growth, has been verified by numerous studies and their results are mixed. Some studies follow the idea that migration is negatively correlated with the convergence between regions (Blanchard, Katz, 1992 Dolado, 1993), while other case studies have shown positive effects on growth (Barro, Sala-i-Martin 1992 ).

In terms of determining the reasons for the decision to migrate, they remain individual, so related to the personal choice. The purposes of the emigrants (especially those with higher education) refers to: the desire to improve the quality of life, the accumulation of resources, scholarships, (in which case the chances to return to the country drop dramatically), etc (Cismas et al, 2009).

Regarding the migration of highly skilled labor, most studies have demonstrated that it has the tendency to migrate to countries or regions where the human capital is better rewarded (Roman et al, 2008). Migration depending on the skill level was tested by Hunt and Muller (2004). They reiterated, based on the realities of Canada and the USA, that highly qualified people are attracted to countries with higher wages. Traditional studies have shown that the labor product average and the average income per capita are negatively influenced by highly qualified labor migration (Bhagwati, Hamada, 1974).

The impact on the labor market has not yet been well defined, especially in the source countries. Some papers claim that the positive effects predominate (the chance of returning to the country of origin through the transfer of knowledge), and other studies emphasize the negative consequences of loss of the human capital, and thus innovative potentially (Borjas, Card, 2005).

Another point of view was studying the situation in which highly skilled labor migration may lead to the creation of business networks (Kim, Lee, 2016). By the highly skilled workforce influences, returned to their countries of origin, and by the large diasporas from the developed, new technologies and innovation resources are transferred to the source countries (Rauch, Trinidad, 2002; Stark et al., 1997). This process creates a network of highly qualified workforce related to country of origin, and further, raises the possibility of the foreign direct investment contracts between countries of origin and countries of destination. Recent studies have argued that the relatively high rates of highly qualified migrants generate increased volume of foreign direct investment in source economies (Docquier and Lodigiani, 2010).

This idea is contrary to Samuelson's theory, who considers the relationship between migration and trade (FDI) is a relationship of substitutability, because trade contributes to factor price equalization and therefore, it lowers the incentives for factor mobility (Kim, Lee, 
2016). The transaction cost between destination and origin countries is reduced by the participation of emigrants, accelerated rates of growth in the origin countries. Other studies argued about the timing effect of the emigrants over the FDI inflows. Kugler (2004) considers that skilled workforce migration and FDI inflows are negatively correlated simultaneously and contemporaneously. He considers that there are no immediately effects between the firms and the workers and that it takes much time until the highly skilled workers can positive influence the FDI inflows, through the trade network.

Considering this theory, we intend to check if there is a correlation between the total number of emigrants (including the high skilled workforce) and the FDI inflows, in Romania last 7 years.

\section{Data and methodology}

The period under observation is the interval 2008-2015, the period for which data are available. The data sources are: The National Institute of Statistics, the database queries Tempo-Online, National Bank of Romania. The data were processed, summarized and sorted, resulting tables and graphs obtained in Excel and E-Views software. To achieve the econometric model, designed to test the relationship between competitiveness, emigration and foreign direct investment, we chose the following variables:

Gross domestic product - as a measure of the national competitiveness;

Temporary and permanent emigration - expressed in absolute value, for persons aged 24-59 years;

FDI - expressed in million EUR.

In theory, the paper aims to verify whether emigration, especially among the highly skilled workforce, influences the national competitiveness (expressed as GDP) growth, and the foreign direct investments. At the practical level, the paper makes a quantitative analysis of the relationship between these variables.

\section{Results}

Table 1: Descriptive Statistics

$\begin{array}{lccc} & \text { EMIGRANTI } & \text { ISD } & \text { PIB } \\ \text { Mean } & 12487.78 & 3627.735 & 9337.105 \\ \text { Median } & 15512.88 & 4273.708 & 9798.794 \\ \text { Maximum } & 25961.25 & 5369.417 & 13168.57 \\ \text { Minimum } & 735.8333 & 61.31944 & 4606.437 \\ \text { Std. Dev. } & 8647.848 & 1656.183 & 2648.857 \\ \text { Skewness } & -0.324599 & -0.940743 & -0.411603 \\ \text { Kurtosis } & 1.686801 & 2.527966 & 2.011336 \\ & & & \\ \text { Jarque-Bera } & 12.87568 & 22.57685 & 9.930747 \\ \text { Probability } & 0.001600 & 0.000013 & 0.006975 \\ & & & \\ \text { Sum } & 1798241 . & 522393.8 & 1344543 . \\ \text { Sum Sq. Dev. } & 1.07 \mathrm{E}+10 & 3.92 \mathrm{E}+08 & 1.00 \mathrm{E}+09 \\ & & & \\ \text { Observations } & 144 & 144 & 144\end{array}$

Source: own calculations, based on the National Institute of Statistics data, processed in E-views 
The generated analysis, based on 144 observations on average, median, maximum and minimum values of the indicators shows the differences between emigrants and dependent variables FDI and GDP. The minimum and maximum amount of indicators show the influence of the emigrants over the other two analyzed variables.

\section{EMIGRANTS}

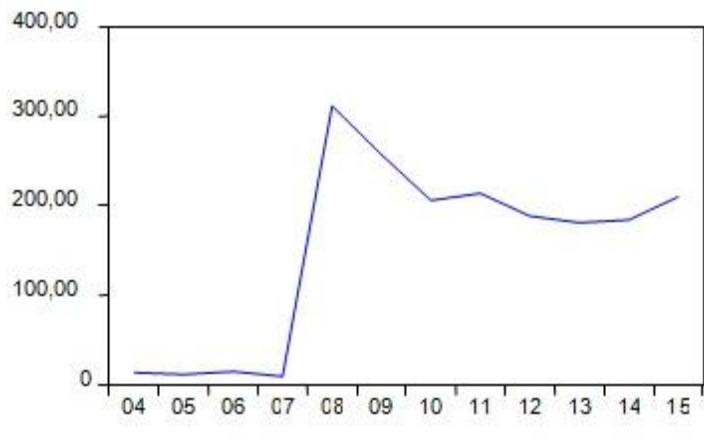

FDI

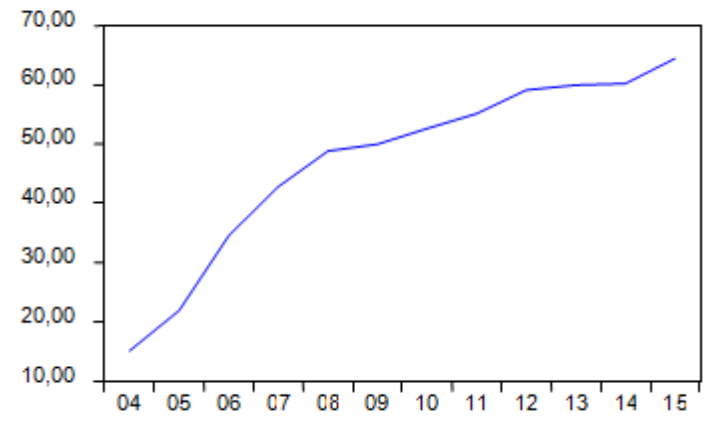

GDP

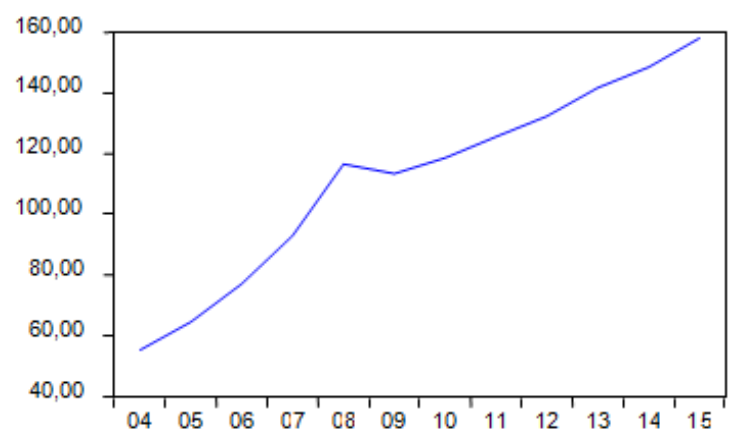

Figure 1: The evolution of the GDP, FDI and the emigrants between 2004 - 2015.

Source: own calculations, based on the National Institute of Statistics data, processed in E-views

Figure 1 shows that evolution of the foreign investment and gross domestic product have been in continuous ascent. The exception is the number of emigrants who suddenly decreased, then stalled and then it resumed its upward trend, without reaching the maximum previously recorded. 
Dependent Variable: FDI

Method: Least Squares

Sample: 1144

Included observations: 144

\begin{tabular}{lrlll}
\hline \hline \multicolumn{1}{c}{ Variable } & Coefficient & Std. Error & t-Statistic & Prob. \\
\hline \hline \multicolumn{1}{c}{ EMIGRANTI } & 0.154976 & 0.009442 & 16.41312 & 0.0000 \\
\multicolumn{1}{c}{ C } & 1692.428 & 143.2637 & 11.81338 & 0.0000 \\
\hline \hline R-squared & 0.654829 & Mean dependent var & 3627.735 \\
Adjusted R-squared & 0.652398 & S.D. dependent var & 1656.183 \\
S.E. of regression & 976.4486 & Akaike info criterion & 16.61951 \\
Sum squared resid & $1.35 \mathrm{E}+08$ & Schwarz criterion & 16.66076 \\
Log likelihood & -1194.605 & Hannan-Quinn criter. & 16.63627 \\
F-statistic & 269.3904 & Durbin-Watson stat & 0.079907 \\
Prob(F-statistic) & 0.000000 & & & \\
\hline
\end{tabular}

Testing the emigrant's influence on FDI and GDP, we started from the following simple linear regression:

$\mathrm{FDI}=$ dependent variable;

FDI $=\alpha+\beta^{\star} E M I G R A N T S$, where,

$\alpha=$ constant;

$\beta=$ independent variable parameter;

EMIGRANTS= independent variable

Following to quantify the relation between the foreign direct investments and the number of the emigrants, the obtained results show that $\alpha=1692.428$, and $\beta=0.154976$, which means,

$$
F D I=1692.4283+0.154976{ }^{\star} E M I G R A N T S .
$$

The value of the F-Test tests how much the independent variable explains the evolution of the dependent variable. The R-Squared value shows if the regression model is well specified, and also, what percentage of the total variance of the dependent variable is due to the independent variable. In our case, the value of R-Squared $(0.654)$, tests that $65.4 \%$ of FDI is explained by the number of emigrants. In the same time, the difference until $100 \%$ (1), is covered by other factors, like the economic stability, the freedom of movement, etc. The value of the estimated parameter is 0.154976 , meaning that a $1 \%$ increase of the number of emigrants causes an increase in total FDI with 0.154976 . The value of the Standard Error explains the dependence of the analyzed variable FDI.

To check if the series are positively or negatively correlated, we chose the Durbin-Watson test. Given the fact that $0.79<2$, results that the series are positively correlated. 
Dependent Variable: GDP

Method: Least Squares

Sample: 1144

Included observations: 144

\begin{tabular}{lrlll}
\hline \hline \multicolumn{1}{c}{ Variable } & Coefficient & Std. Error & t-Statistic & Prob. \\
\hline \hline \multicolumn{1}{c}{ EMIGRANTS } & 0.230730 & 0.016906 & 13.64793 & 0.0000 \\
$\quad$ C & 6455.797 & 256.5076 & 25.16806 & 0.0000 \\
\hline \hline R-squared & 0.567424 & Mean dependent var & 9337.105 \\
Adjusted R-squared & 0.564378 & S.D. dependent var & 2648.857 \\
S.E. of regression & 1748.290 & Akaike info criterion & 17.78446 \\
Sum squared resid & $4.34 \mathrm{E}+08$ & Schwarz criterion & 17.82570 \\
Log likelihood & -1278.481 & Hannan-Quinn criter. & 17.80122 \\
F-statistic & 186.2661 & Durbin-Watson stat & 0.054434 \\
Prob(F-statistic) & 0.000000 & & & \\
\hline \hline
\end{tabular}

Using the same regression model for the second test, we obtained:

$$
G D P=\alpha+\beta^{\star} E M I G R A N T S \text {, where }
$$

$\mathrm{GDP}=$ dependent variable

$\alpha=$ constant

$\beta=$ independent variable parameter

EMIGRANTS= independent variable

After replacing the obtained values, the equation becomes:

$$
G D P=6455.797+0.230730^{\star} E M I G R A N T S
$$

The value of R-Squared is 0.5674 , meaning that $56.74 \%$ of GDP is explained by the number of the emigrants. Of course, there are other factors that influence the GDP, for the analyzed period, the financial crisis being an important one. The parameter value is 0.230 , which means that a $1 \%$ increase in the number of the emigrants causes an increase in total GDP with 0.230730 .

The both obtained results are showing that, even if a positive correlation exist, the emigrants didn't have a significative influence over the FDI inflow, and over de GDP. Remittances have contributed to raising living standards, but didn't turn into private investments or personal savings. The emigrants experience and their typology hasn't generated a business partnership between the source country and the destination country.

Regarding the emigration of highly qualified influence (approx. $20 \%$ of the total), has not manifested itself in a decisive way on FDI and GDP.

The Durbin-Watson test value is 0.054 , less than 2 , which come to the conclusions that the series are positively correlated. 


\section{Conclusions}

The effects of the highly skilled migration on the labor market for Romanian and private sector performance is focused on:

- the reduced degree of specialization of labor, the departure of highly qualified, unmet wage levels and working conditions; they are prone to remain in the country of destination, determined by the attractiveness of the environment;

- lowering the quality of local goods and services by replacing permanent staff caused by the intention to migrate; this leads to increased labor costs and reduce productivity; Romanian private sector warned of the difficulty of recruiting qualified personnel and called on the national authorities to promote the country return;

- Weakening the training effect on certain key areas of the Romanian economy, with high potential in the field of IT or research in medicine; reduced budgetary allocations for R\&D hinders development areas in which Romania can become competitive and hence the related sectors;

The statistical data and the forecasts are showing that, for Romania, human capital is a too "expensive" resource to be "exported" in such a large number. First, is a waste of added value that could be achieved in the country, a loss of economic growth sources in the long term, a lack of economic activities capitalization (with real expression in taxes, profits, salaries, contributions to foreign investment, etc.). Secondly, the lack of capitalization of public spending in education is equivalent to "sponsorship" the destination countries, with a highly qualified workforce at lower costs than the domestic ones. Lastly, the technological advancement and the innovation were weakened by the migratory attitude of the Romanian citizens. In this way the negative effects occur on productivity and national competitiveness, especially by raising employment deficits, depending on the level of education and areas of activity.

The positive effects focus on easing the labor market, reducing the unemployment, and reducing the pressure on the state on the allocation of social funds from the public budget. Analyzing the cost-benefit of migratory flux in Romania, we find that, at present, increasing the number of emigrants would lead to weakening the competitive forces of Romania. Therefore we believe that the authorities should consider the following measures:

- Promoting fiscal programs for the private sector, encouraging the employment of specialists in competitive wage. In fact, the intention to migrate is influenced by the dynamics and the productivity of the private sector, and local communities are those that can influence it to a large extent;

- Initiating effective rewards to induce the emigrants to return home. This would involve implementing strategies to capitalize the human resources potential, guaranteeing higher requirements jobs, involving the best specialists in the local/regional recognition management, facilitating access to the labor market.

- Improving the public-private partnership, by encouraging young highly skilled graduates to work in Romania.

\section{References}

Annoni, P., Dijkstra, L. (2013). EU Regional Competitiveness Index RCI 2013. Joint Research Center, Scientific and Policy Reports. European Commision.

Arslan, C. et al. (2014). 'A New Profile of Migrants in the Aftermath of the Recent Economic Crisis', OECD Social, Employment and Migration Working Papers, no. 160, OECD Publishing.

Barro, R., J., Sala-i-Martin-X. (1995). Economic Growth, New York: McGraw-Hill.

Bhagwati, J., Hamado, K. (2003). 'The Brain Drain International Integration of Markets for Professionals and Unemployment: A Theoretical Analysis', Journal of Development Economics, vol. 1, no. 1, pp. 19-42. 
Blanchard, O., Kaptz, L. (1992). 'Regional Evolutions', Brooking Papers on Economic Activity, 1, pp. 1-61.

Borjas, G., J. (2005). 'The Labor Market Impact of High Skill Immigration', American Economic Review, vol. 95, no. 2, pp. 56-60.

Boshma, R. (2004). 'Competitiveness of Region from an Evolutionary Perspective', Regional studies, vol. 38, no. 9, pp.1001-1014.

Card, D. (2005), 'Is The New Immigration Really So Bad?', Economic Journal, vol. 115, no. 507, pp. 300-323.

Cismaş, L., M., Muţiu F., Asproniu, A. (2009). Globalisation, Migration, Mobility and Human Rights: Romanian Perspectives under the Influence of the Global Crisis, Universitatea de Vest din Timişoara.

Cismas, L., Sîrghi, N. (2013). Quality Assurance in Education by Linking the Romanian Academic System to Europe 2020 Objectives. Timişoara.

Gardiner, Martin, R., Tyler, P. (2004). Competitiveness, Productivity and Economic Growth across the European Regions, University of Cambridge.

Kim, J., Lee, N., Y. (2016). 'The Effect of High Skilled Emigration, Foreign Direct Investment and Policy on the Growth Rate of Source Countries: A Panel Analysis'. East Asian Economic Review, vol. 20, no. 2, pp. 229-275.

Kugler, M. and H. Rapoport, (2004) "Skilled Emigration, Business Networks and Foreign Direct Investment," CESIFO Area Conference on Global Economy.Munich, available at http://el.mouhoub.mouhoud.free.fr/wp-content/kuegler-et-rapoport.pdf, [28.01.2017]

Lindsay Lowell B., Findlay A. (2001). Migration Of Highly Skilled Persons From Developing Countries: Impact And Policy Responses Draft Synthesis Report, p.10, available from: https://www.researchgate.net/publication/237112464 [03.02.2017].

Lowell, B. L., Findlay, A. (2007). Migration of highly skilled persons from developing countries: impact and policy responses, International Labour Office Department for International Development, Uk Project Int/01/M09/Ukm: Skilled Labour Migration (The "Brain Drain") From Developing Countries: Analysis Of Impact And Policy Issues.

National Institute of Statistics, Tempo Online Statistics, available from: http://statistici.insse.ro/shop/?lang=ro [17.02.2017]

OECD (1996). Trends in international migration, continuous reporting system on migration annual report, OECD.

Roman, M., Jaba, E., Goschin, Z., Heanu, B. (2008). Human Capital of Romanian Emigrants in Europe, paper supported by CNCSIS grant IDEI 1829/2008: The Effects of Labor Force Migration and Demographical Structural Changes on the Dynamic of Economics.

Stark, O., Helmenstein, C., Prskawetz, A. (1997). 'A Brain Gain with a Brain Drain', Economics Letters, vol. 55, no. 2, pp. 227-234.

The National Bank of Romania, Foreign direct investment in Romania - annual report, available from: http://www.bnr.ro/PublicationDocuments.aspx?icid=9403 [02.02.2017].

Trinidate, V., Rauch, J., E. (2002). 'Ethnic Chinese Networks in International Trade', Review Of Economics And Statistics, vol. 84, no. 1, pp. 116-130.

United Nations (2013). World Migration in Figures, A joint contribution by UN-DESA and the OECD to the United Nations High-Level Dialogue on Migration and Development, Department of economic and Social Affairs2013, OECD-UNDESA. 


\section{Bio-note}

Ana Maria Talmaciu (Banu) is a Ph.D. candidate at Faculty of Economics and Business Administration, West University of Timisoara, Romania. Her interests include Economy, Competitiveness, Economic Forecast, European Union Economiy, Society. Her thesis is on Romania's competitiveness in relation to the Europe 2020 targets. Until now she presented 4 scientific papers at International Conferences and 1 at National Conferences.

Prof. Laura-Mariana Cismaş, PhD., Director of the Economics and Business Modelling Department, West University of Timisoara, Faculty of Economy and Business Administration, Departament of Economy, is specialized in Economy, Microeconomics, Macroeconomics, Political economics, International Economics, European Union Economy, European Social Model Details. She has numerous scientific papers presented and published in prestigious journals along with books and courses. 